\title{
Analysis of the Regions in Terms of Promoting Regional Development of Republic of Macedonia
}

\author{
Jankulovski Nikolche $^{1}$, Angelova Biljana ${ }^{2}$, Dojchinovski Trajan ${ }^{1}$, Bojkovska Katerina ${ }^{1}$, Arapcheska Mila ${ }^{1} \&$ \\ Jankulovska Angjelka ${ }^{1}$ \\ ${ }^{1}$ University St. Kliment Ohridski-Bitola, Bitola, Republic of Macedonia \\ ${ }^{2}$ University St. Ciryl and Methodius-Skopje, Republic of Macedonia \\ Correspondence: Jankulovski Nikolche, University St. Kliment Ohridski-Bitola, Republic of Macedonia. Tel: \\ 389-75-401-005. E-mail: nikolcejankulovski@yahoo.com
}

Received: September 10, 2015

doi:10.5539/ijef.v7n10p247
Accepted: September 26, $2015 \quad$ Online Published: September 30, 2015

URL: http://dx.doi.org/10.5539/ijef.v7n10p247

\begin{abstract}
The regional development is complex and long-term process, which main objective is decreasing differences in development within the planning regions. The complexity of the regional development is based on its multidimensionality, which implies presence of multiple elements, including: economic, social, spacious, cultural and many other elements of the development. Therefore, the successful implementation of the strategies and policies for regional development is in direct dependence on overall awareness of the concept of regional development, efficient connection of the regional development policy with the sectoral policies, and providing the necessary support by the relevant institutions.

The main objective of this thesis is to indicate the disparities between regions in direction of encouraging and developing balanced regional development of the Republic of Macedonia.

For the purpose of this research comparative analysis of the condition of the economic development of Local Government Units of Republic of Macedonia is being conducted.
\end{abstract}

Keywords: regional development, economic development, budget, planning

\section{Introduction}

The procedure for sample selection was based on principle for making regional representative sample, which will define the region in accordance to its definition by the State Statistical office of the Republic of Macedonia. (Note 1) According to data base, which is made on basis of the following indicators: GDP per capita at municipal level, number of citizens in the municipality, size of the territory of the municipality and number of settlements that gravitate towards the municipality, there are 22 municipalities (Note 2) in the realized total sample, from each planning region in the country, representing $30 \%$ of the municipalities from each planning region.

For the purpose of the reasearch comparative analysis of the conditions in the Local Government Unitsis being conducted. The analysis of the indicators that refer to economic-social index (total incomes in terms of GDP, total expenses in terms of GDP), analysis of financial capacity of municipalities in Republic of Macedonia (capacity and structure of original incomes, capacity and structure of budget transfers and donations, participation of municipalities' original incomes in the total budget revenue) shall be presented in this thesis, and a matrix of indicators for incomes and expenses per planning region will be presented.

Criteria for determining municipalities which represent the sample for examining the fiscal indicators and indicators for expenses were created for processing of data that are necessary for measuring the unevenness in the development of planning regions. The criteria that are the base of the research and data processing from all 84 municipalities in the Republic of Macedonia are following:

1). Number of citizens in the municipality:

- Large municipalities (over 50.000 citizens);

- Middle municipalities (10.000 - 50.000 citizens);

- Small municipalities (below 10,000 citizens). 
2). Number of settlements that gravitate towards the municipality:

- Large municipalities (over 50 settlements);

- Middle municipalities (10 - 50 settlements);

- Small municipalities (less than 10 settlements).

3). Size of the territory of the municipality:

- Large municipalities (above $780 \mathrm{~km}^{2}$ );

- Middle municipalities $\left(390-780 \mathrm{~km}^{2}\right)$;

- Small municipalities (below $390 \mathrm{~km}^{2}$ ).

4). Level of gross domestic product per capita in the municipality:

- Large municipalities (35060,30 - 51405,80 MKD per capita);

- Middle municipalities (18714,70 - 35060,29 MKD per capita);

- Small municipalities (2369,00 - 18714,69 MKD per capita).

5). At least one Local Government Unit from each planning region must be rural municipality.

According to presented data from the detail review, in the representative sample there are $30 \%$ from total number of municipalities that meet the criteria, separately from each planning region. Vardar planning region-three from nine municipalities, Eastern planning region-3 from 11 municipalities, Southwestern planning region-3 from 11 municipalities, Southeastern planning region-3 from 9 municipalities, Pelagonija planning region-3 from nine municipalities, Polog planning region-2 from 8 municipalities, Northeastern planning region-2 from 7 municipalities and Skopje planning region-3 from 11 municipalities.

Mostly half of the selected municipalities from the researched Local Government Units will be rural municipalities. The municipalities, which are subject of the research, are presented in the next chart 2.

\section{Analysis of Total Budget Revenue and Expenses in Terms of Gross Domestic Product per Purchasing Power Parity in Local Government Units}

The basic two indicators in all Local Government Units in the Republic of Macedonia are incomes and expenses. These two indicators are broken down into a number of sub-indicators, according to the official classification of revenue and expense items of Local Government in Republic of Macedonia.

One of the most commonly used and recognizable methods for determining the level of fiscal decentralization in almost every developed country is participation of total incomes and expenses of Local Government Units in the gross domestic product of each country. The total incomes and expenses from all Local Government Units of Republic of Macedonia, processed from LGU's concluding sheets, i.e. their percentage share in GDP per PPP of municipality in MKD.

Table 1. Budget revenue in terms of GDP per planning regions for 2010, 2011 and 2012

\begin{tabular}{lccc}
\hline REALIZATION PER YEAR & 2010 & 2011 & 2012 \\
\hline Vardar region & & & \\
\hline Veles & $1,10 \%$ & $3,20 \%$ & $4,40 \%$ \\
Kavadarci & $4,30 \%$ & $4,60 \%$ & $6,00 \%$ \\
Caska & $1,40 \%$ & $3,90 \%$ & $4,60 \%$ \\
\hline Eastern region & & & \\
\hline Stip & $1,30 \%$ & $3,90 \%$ & $5,80 \%$ \\
Probistip & $1,80 \%$ & $3,40 \%$ & $6,30 \%$ \\
Berovo & $4,70 \%$ & $4,20 \%$ & $4,80 \%$ \\
\hline Southwestern region & & & \\
\hline Kicevo & $3,60 \%$ & $4,30 \%$ & $5,90 \%$ \\
Makedonskibrod & $2,20 \%$ & $4,90 \%$ & $13,60 \%$ \\
Oslomej & $2,90 \%$ & $3,00 \%$ & $3,50 \%$ \\
\hline Southeastern region & & & \\
\hline Strumica & $5,60 \%$ & $4,80 \%$ & $6,30 \%$ \\
Valandovo & $4,60 \%$ & $3,90 \%$ & $3,60 \%$ \\
Dojran & $6,20 \%$ & $6,20 \%$ & $11,50 \%$ \\
\hline
\end{tabular}




\begin{tabular}{llll}
\hline Pelagonija region & & & \\
\hline Bitola & $4,00 \%$ & $4,00 \%$ & $4,80 \%$ \\
Prilep & $3,70 \%$ & $3,90 \%$ & $4,70 \%$ \\
DemirHisar & $3,60 \%$ & $3,80 \%$ & $4,60 \%$ \\
\hline Polog region & & & \\
\hline Gostivar & $0,90 \%$ & $3,50 \%$ & $4,20 \%$ \\
Bogovinje & $1,60 \%$ & $1,90 \%$ & $1,80 \%$ \\
\hline Northeastern region & & & \\
\hline Kumanovo & $3,80 \%$ & $3,90 \%$ & $4,00 \%$ \\
Kratovo & $2,30 \%$ & $3,60 \%$ & $6,10 \%$ \\
\hline Skopje region & & & \\
\hline Centar & $7,80 \%$ & $11,30 \%$ & $19,40 \%$ \\
KiselaVoda & $3,10 \%$ & $3,40 \%$ & $5,20 \%$ \\
Saraj & $2,40 \%$ & $0,60 \%$ & $1,30 \%$ \\
\hline
\end{tabular}

Source: Own processing based on official data from the State Statistical Office of Republic of Macedonia and Finance Departments in all Local Government Units in Republic of Macedonia.

Table 2. Budget expenses in terms of GDP, per planning regions for 2010, 2011 and 2012

\begin{tabular}{|c|c|c|c|}
\hline REALIZATION PER YEAR & 2010 & 2011 & 2012 \\
\hline \multicolumn{4}{|l|}{ Vardar region } \\
\hline Veles & $1,00 \%$ & $3,20 \%$ & $4,40 \%$ \\
\hline Kavadarci & $4,00 \%$ & $4,50 \%$ & $6,00 \%$ \\
\hline Caska & $1,30 \%$ & $3,90 \%$ & $4,60 \%$ \\
\hline \multicolumn{4}{|l|}{ Eastern region } \\
\hline Stip & $1,20 \%$ & $3,90 \%$ & $5,80 \%$ \\
\hline Probistip & $1,70 \%$ & $3,40 \%$ & $6,30 \%$ \\
\hline Berovo & $4,40 \%$ & $4,20 \%$ & $4,80 \%$ \\
\hline \multicolumn{4}{|l|}{ Southwestern region } \\
\hline Kicevo & $3,50 \%$ & $4,30 \%$ & $5,90 \%$ \\
\hline Makedonskibrod & $2,20 \%$ & $4,90 \%$ & $13,60 \%$ \\
\hline Oslomej & $2,70 \%$ & $3,00 \%$ & $3,50 \%$ \\
\hline \multicolumn{4}{|l|}{ Southeastern region } \\
\hline Strumica & $5,50 \%$ & $4,80 \%$ & $6,30 \%$ \\
\hline Valandovo & $4,00 \%$ & $3,80 \%$ & $3,60 \%$ \\
\hline Dojran & $5,40 \%$ & $5,80 \%$ & $11,50 \%$ \\
\hline \multicolumn{4}{|l|}{ Pelagonija region } \\
\hline Bitola & $3,70 \%$ & $3,90 \%$ & $4,80 \%$ \\
\hline Prilep & $1,20 \%$ & $3,80 \%$ & $4,70 \%$ \\
\hline DemirHisar & $3,50 \%$ & $3,70 \%$ & $4,60 \%$ \\
\hline \multicolumn{4}{|l|}{ Polog region } \\
\hline Gostivar & $0,90 \%$ & $3,30 \%$ & $1,40 \%$ \\
\hline Bogovinje & $1,80 \%$ & $1,70 \%$ & $1,10 \%$ \\
\hline \multicolumn{4}{|l|}{ Northeastern region } \\
\hline Kumanovo & $3,70 \%$ & $3,80 \%$ & $3,90 \%$ \\
\hline Kratovo & $2,30 \%$ & $3,60 \%$ & $6,10 \%$ \\
\hline \multicolumn{4}{|l|}{ Skopje region } \\
\hline Centar & $6,60 \%$ & $9,90 \%$ & $19,10 \%$ \\
\hline KiselaVoda & $2,00 \%$ & $3,20 \%$ & $5,70 \%$ \\
\hline Saraj & $2,30 \%$ & $0,60 \%$ & $1,30 \%$ \\
\hline
\end{tabular}

Source: Own processing based on official data from the State Statistical Office of Republic of Macedonia and Finance Departments in all Local Government Units in Republic of Macedonia.

From the analysis, it can be ascertained that in the analyzed period, there is an increase of local incomes and expenses in Republic of Macedonia. This is a result of increasing the tax base and improving the municipality 
tax payment (total incomes), that is the increase of competences from central to local level, without appropriate level of transfers for their financing (total expenses).

\section{Analysis of Indicators of Incomes and Indicators of Expenses per Planning Regions}

The presented analysis of the characteristics for development of planning regions provides insight in the existing condition into a number of segments significant for regional development. Starting from the big disparities between the planning regions development, the focus in the analysis is put on interregional differences. The identification of disparities and wherever possible - the reasons for their occurrence, is made in order to obtain solid base for planning the regional development.

\subsection{Vardar Planning Region}

According to previously determined criteria for research realization, the municipalities Veles, Kavadarci and Caska were subject of research in Vardar planning region.

Table 3. Indicators of incomes and indicators of expenses, Vardar planning region, 2010, 2011 and 2012

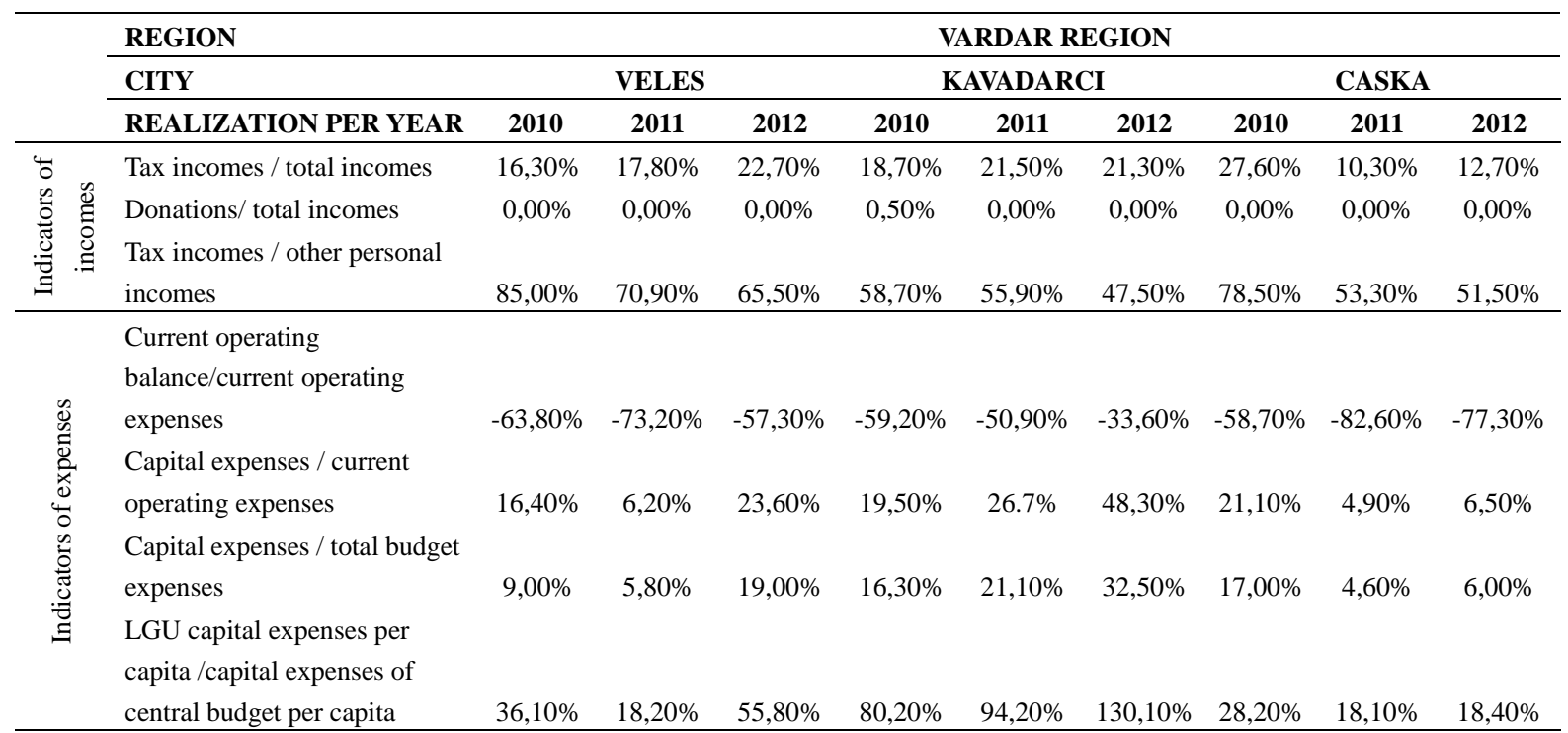

Source: Own processing based on official data from the State Statistical Office of Republic of Macedonia and Finance Departments in all Local Government Units in Republic of Macedonia.

In the analyzed period, there is a small increase in participation of tax incomes in total incomes, excluding rural municipalities (Caska), which indicates the fact that urban municipalities from Vardar planning region are in condition to generate increased level of tax incomes, which is a result of increasing the range of tax base, as well as the influence of increased fiscal effort due to transfer of competences from local to central level.

In the balance of current operating activities in terms of current operating expenses negative values are noted, which represents absence of credit potential of Local Government Units from this planning region for taking credit liabilities (borrowings).

Excluding rural municipalities, Vardar planning region also notes increase of capital expenses in terms of level of accomplishment of current operating expenses. This indicates high level of realization of financial resources intended for capital projects. This indicator indicates nearly same engagement of financial resources for current operating purposes, as for realization of capital projects. This is sufficient ascertainment for the commitment of Vardar planning region in the realization of capital projects.

Analyzing the balance of capital expenses in terms of total budget expenses, it can be ascertained that the level of investing activity of municipalities from this region is relatively stable. This condition is a result of increased budget expenses in the analyzed period.

\subsection{Eastern Planning Region}

According to previously determined criteria for research realization, the municipalities Stip, Probistip and Berovo were subject of research in Eastern planning region. 
Table 4. Fiscal indicators and indicators of expenses, Eastern planning region, 2010, 2011 and 2012

\begin{tabular}{|c|c|c|c|c|c|c|c|c|c|c|}
\hline & \multirow{3}{*}{$\begin{array}{l}\text { REGION } \\
\text { CITY } \\
\text { REALIZATION PER YEAR } \\
\end{array}$} & \multicolumn{9}{|c|}{ EASTERN REGION } \\
\hline & & \multicolumn{3}{|c|}{ STIP } & \multicolumn{3}{|c|}{ PROBISTIP } & \multicolumn{3}{|c|}{ BEROVO } \\
\hline & & 2010 & 2011 & 2012 & 2010 & 2011 & 2012 & 2010 & 2011 & 2012 \\
\hline \multirow{3}{*}{ 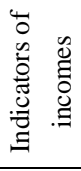 } & Tax incomes / total incomes & $24,1 \%$ & $26,30 \%$ & $29,11 \%$ & $23,10 \%$ & $12,90 \%$ & $12,80 \%$ & $11,30 \%$ & $10,80 \%$ & $11,50 \%$ \\
\hline & Donations/ total incomes & $0 \%$ & $1,4 \%$ & $2,10 \%$ & $5,90 \%$ & $0,00 \%$ & $4,10 \%$ & $7,20 \%$ & $5,00 \%$ & $6,60 \%$ \\
\hline & $\begin{array}{l}\text { Tax incomes / other personal } \\
\text { incomes }\end{array}$ & $87,40 \%$ & $78,60 \%$ & $73,60 \%$ & $50,10 \%$ & $39,70 \%$ & $26,60 \%$ & $72,90 \%$ & $67,50 \%$ & $57,40 \%$ \\
\hline \multirow{4}{*}{ 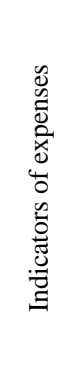 } & $\begin{array}{l}\text { Current operating balance / } \\
\text { current operating expenses }\end{array}$ & $-59,50 \%$ & $-63,30 \%$ & $-46,00 \%$ & $-35,50 \%$ & $-64,60 \%$ & $-26,60 \%$ & $-79,50 \%$ & $-81,20 \%$ & $-76,20 \%$ \\
\hline & $\begin{array}{l}\text { Capital expenses / current } \\
\text { operating expenses }\end{array}$ & $7,80 \%$ & $9,10 \%$ & $27,00 \%$ & $31,40 \%$ & $16,40 \%$ & $35,70 \%$ & $19,00 \%$ & $15,60 \%$ & $16,00 \%$ \\
\hline & $\begin{array}{l}\text { Capital expenses / total } \\
\text { budget expenses }\end{array}$ & $11,5 \%$ & $10,00 \%$ & $37,10 \%$ & $45,70 \%$ & $19,60 \%$ & $55,70 \%$ & $23,50 \%$ & $18,50 \%$ & $19,10 \%$ \\
\hline & $\begin{array}{l}\text { LGU capital expenses per } \\
\text { capita /capital expenses of } \\
\text { central budget per capita }\end{array}$ & $34,10 \%$ & $34,60 \%$ & $105,20 \%$ & $66,40 \%$ & $54,30 \%$ & $151,40 \%$ & $101,10 \%$ & $64,20 \%$ & $51,60 \%$ \\
\hline
\end{tabular}

Source: Own processing based on official data from the State Statistical Office of Republic of Macedonia and Finance Departments in all Local Government Units in Republic of Macedonia.

Regarding the tax incomes in terms of total incomes, certain flexibility of this trend is noticed. This indicates the fact that bigger Local Government Units from Eastern planning region are in condition to generate stable level of tax incomes, which is a result of increased tax base, as well as the influence of increased fiscal effort due to transfer of competences from local to central level.

In the balance of current operating activities in terms of current operating expenses negative values are noted, which represents absence of credit potential of Local Government Units from this planning region for taking credit liabilities (borrowings).

Eastern planning region also notes increase of capital expenses in terms of level of accomplishment of current operating expenses. This indicates high level of realization of financial resources intended for capital projects. This indicator indicates nearly same engagement of financial resources for current operating purposes, as for realization of capital projects. This is sufficient ascertainment for the commitment of Vardar planning region in the realization of capital projects.

Analyzing the balance of capital expenses in terms of total budget expenses, it can be ascertained that the level of investing activity of municipalities from this region is relatively stable. This condition is a result of increased budget expenses in the analyzed period.

According to previously determined criteria for research realization, the municipalities Kicevo, Makedonski Brod and Oslomej were subject of research in Southwestern planning region.

\subsection{Southwestern Planning Region}

In the analyzed period, there is a small increase in participation of tax incomes in total incomes (at bigger municipalities), which indicates the fact that urban municipalities from Southwestern planning region are in condition to generate increased level of tax incomes, which is a result of increasing the range of tax base, as well as the influence of increased fiscal effort due to transfer of competences from local to central level.

In the balance of current operating activities in terms of current operating expenses negative values are noted, which represents absence of credit potential of Local Government Units from this planning region for taking credit liabilities (borrowings).

Excluding rural municipalities, Southwestern planning region also notes increase of capital expenses in terms of level of accomplishment of current operating expenses. This indicates high level of realization of financial resources intended for capital projects. This indicator indicates nearly same engagement of financial resources for current operating purposes, as for realization of capital projects. This is sufficient ascertainment for the commitment of Southwestern planning region in the realization of capital projects.

Analyzing the balance of capital expenses in terms of total budget expenses, it can be ascertained that they are increased, which indicates increase of the level of investing activity of municipalities from this region. This 
condition is a result of increased budget expenses in the analyzed period.

Table 5. Fiscal indicators and indicators of expenses, Southwestern planning region, 2010, 2011 and 2012

\begin{tabular}{|c|c|c|c|c|c|c|c|c|c|c|}
\hline & \multirow{3}{*}{$\begin{array}{l}\text { REGION } \\
\text { CITY } \\
\text { REALIZATION PER YEAR } \\
\end{array}$} & \multicolumn{9}{|c|}{ SOUTHWESTERN PLANNING REGION } \\
\hline & & \multicolumn{3}{|c|}{ KICEVO } & \multicolumn{3}{|c|}{ MAKEDONSKI BROD } & \multicolumn{3}{|c|}{ OSLOMEJ } \\
\hline & & 2010 & 2011 & 2012 & 2010 & 2011 & 2012 & 2010 & 2011 & 2012 \\
\hline \multirow{3}{*}{ 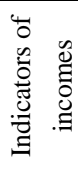 } & Tax incomes / total incomes & $21,10 \%$ & $24,90 \%$ & $20,20 \%$ & $20,60 \%$ & $10,00 \%$ & $6,30 \%$ & $7,50 \%$ & $8,40 \%$ & $10,70 \%$ \\
\hline & Donations/ total incomes & $0 \%$ & $0,40 \%$ & $0,20 \%$ & $0,00 \%$ & $0,00 \%$ & $27,50 \%$ & $0,00 \%$ & $0,00 \%$ & $0,00 \%$ \\
\hline & $\begin{array}{l}\text { Tax incomes / other personal } \\
\text { incomes }\end{array}$ & $63,90 \%$ & $77,10 \%$ & $76,50 \%$ & $41,50 \%$ & $52,70 \%$ & $27,40 \%$ & $52,90 \%$ & $52,60 \%$ & $58,30 \%$ \\
\hline \multirow{8}{*}{ 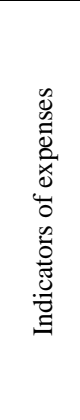 } & Current operating & & & & & & & & & \\
\hline & $\begin{array}{l}\text { balance/current operating } \\
\text { expenses }\end{array}$ & $-61,50 \%$ & $-61,10 \%$ & $-66,40 \%$ & $-26,20 \%$ & $-79,30 \%$ & $-46,10 \%$ & $-83,20 \%$ & $-79,90 \%$ & $-76,80 \%$ \\
\hline & Capital expenses / current & & & & & & & & & \\
\hline & operating expenses & $13,60 \%$ & $16,30 \%$ & $22,70 \%$ & $30,40 \%$ & $8,10 \%$ & $58,30 \%$ & $12,30 \%$ & $19,90 \%$ & $22,30 \%$ \\
\hline & Capital expenses / total budget & & & & & & & & & \\
\hline & expenses & $15,70 \%$ & $19,50 \%$ & $29,70 \%$ & $43,70 \%$ & $8,80 \%$ & $139,90 \%$ & $14,10 \%$ & $24,90 \%$ & $28,90 \%$ \\
\hline & LGU capital expenses per & & & & & & & & & \\
\hline & central budget per capita & $58,30 \%$ & $69,60 \%$ & $89,80 \%$ & $79,40 \%$ & $38,80 \%$ & $532,40 \%$ & $40,90 \%$ & $59,30 \%$ & $52,00 \%$ \\
\hline
\end{tabular}

Source: Own processing based on official data from the State Statistical Office of Republic of Macedonia and Finance Departments in all Local Government Units in Republic of Macedonia.

\subsection{Southeastern Planning Region}

According to previously determined criteria for research realization, the municipalities Strumica, Valandovo and Dojran were subject of research in Southeastern planning region.

Table 6. Fiscal indicators and indicators of expenses, Southeastern planning region, 2010, 2011 and 2012

\begin{tabular}{|c|c|c|c|c|c|c|c|c|c|c|}
\hline & \multirow{3}{*}{$\begin{array}{l}\text { REGION } \\
\text { CITY } \\
\text { REALIZATION PER YEAR }\end{array}$} & \multicolumn{9}{|c|}{ SOUTHEASTERN REGION } \\
\hline & & \multicolumn{3}{|c|}{ STRUMICA } & \multicolumn{3}{|c|}{ VALANDOVO } & \multicolumn{3}{|c|}{ DOJRAN } \\
\hline & & 2010 & 2011 & 2012 & 2010 & 2011 & 2012 & 2010 & 2011 & 2012 \\
\hline \multirow{3}{*}{ 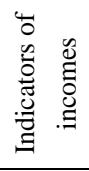 } & Tax incomes / total incomes & $28,10 \%$ & $27.8 \%$ & $28,90 \%$ & $9,40 \%$ & $14,00 \%$ & $12,30 \%$ & $30,80 \%$ & $31,90 \%$ & $24,80 \%$ \\
\hline & Donations/ total incomes & $0.9 \%$ & $0.2 \%$ & $0,60 \%$ & $2,60 \%$ & $0,00 \%$ & $0,30 \%$ & $0,60 \%$ & $9,70 \%$ & $26,70 \%$ \\
\hline & $\begin{array}{l}\text { Tax incomes / other } \\
\text { personal incomes }\end{array}$ & $58.2 \%$ & $67.7 \%$ & $62,20 \%$ & $42,40 \%$ & $64,90 \%$ & $66,80 \%$ & $83,30 \%$ & $71,70 \%$ & $67,60 \%$ \\
\hline \multirow{5}{*}{ 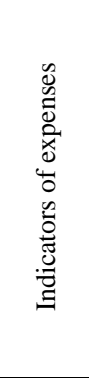 } & $\begin{array}{l}\text { Current operating balance / } \\
\text { current operating expenses }\end{array}$ & $-26,00 \%$ & b $-46,40 \%$ & $-29,70 \%$ & $-71,50 \%$ & $-76,10 \%$ & $-78,30 \%$ & $-40,80 \%$ & $-29,20 \%$ & $-38,90 \%$ \\
\hline & $\begin{array}{l}\text { Capital expenses / current } \\
\text { operating expenses }\end{array}$ & $33,30 \%$ & $23,50 \%$ & $34,00 \%$ & $13,50 \%$ & $10,00 \%$ & $15,40 \%$ & $27,80 \%$ & $32,50 \%$ & $40,10 \%$ \\
\hline & $\begin{array}{l}\text { Capital expenses / total } \\
\text { budget expenses }\end{array}$ & $50.1 \%$ & $30.7 \%$ & $51,70 \%$ & $15,70 \%$ & $11,10 \%$ & $18,20 \%$ & $38,60 \%$ & $48,10 \%$ & $67,30 \%$ \\
\hline & $\begin{array}{l}\text { LGU capital expenses per } \\
\text { capita /capital expenses of }\end{array}$ & & & & & & & & & \\
\hline & central budget per capita & $222,50 \%$ & $6110,30 \%$ & $143,80 \%$ & $13,70 \%$ & $7,80 \%$ & $37,20 \%$ & $181,30 \%$ & $186,70 \%$ & $310,50 \%$ \\
\hline
\end{tabular}

Source: Own processing based on official data from the State Statistical Office of Republic of Macedonia and Finance Departments in all Local Government Units in Republic of Macedonia.

In the analyzed period, there is relatively stable participation of tax incomes in total incomes, excluding rural municipalities, which indicates the fact that urban municipalities from Southeastern planning region are in condition to generate increased level of tax incomes, which is a result of increasing the range of tax base, as well as the influence of increased fiscal effort due to transfer of competences from local to central level. 
In the balance of current operating activities in terms of current operating expenses negative values are noted, which represents absence of credit potential of Local Government Units from this planning region for taking credit liabilities (borrowings).

Excluding rural municipalities, Southeastern planning region also notes small increase of capital expenses in terms of level of accomplishment of current operating expenses. This indicates good level of realization of financial resources intended for capital projects. This indicator indicates nearly same engagement of financial resources for current operating purposes, as for realization of capital projects. This is sufficient ascertainment for the commitment of this planning region in the realization of capital projects.

Analyzing the balance of capital expenses in terms of total budget expenses, it can be ascertained that the level of investing activity of municipalities from this region is relatively stable. This condition is a result of increased budget expenses in the analyzed period.

\subsection{Pelagonija Planning Region}

According to previously determined criteria for research realization, the municipalities Bitola, Prilep and Demir Hisar were subject of research in Pelagonija planning region.

Table 7. Fiscal indicators and indicators of expenses, Pelagonija planning region, 2010, 2011 and 2012

\begin{tabular}{|c|c|c|c|c|c|c|c|c|c|c|}
\hline & \multirow{3}{*}{$\begin{array}{l}\text { REGION } \\
\text { CITY } \\
\text { REALIZATION PER YEAR } \\
\end{array}$} & \multicolumn{9}{|c|}{ PELAGONIJA REGION } \\
\hline & & \multicolumn{3}{|c|}{ BITOLA } & \multicolumn{3}{|c|}{ PRILEP } & \multicolumn{3}{|c|}{ DEMIR HISAR } \\
\hline & & 2010 & 2011 & 2012 & 2010 & 2011 & 2012 & 2010 & 2011 & 2012 \\
\hline \multirow{3}{*}{ 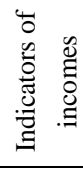 } & Tax incomes / total incomes & $22,90 \%$ & $26,10 \%$ & $32,20 \%$ & $18,20 \%$ & $22 \%$ & $27,50 \%$ & $9,90 \%$ & $14,90 \%$ & $12,30 \%$ \\
\hline & Donations/ total incomes & $0,90 \%$ & $0,70 \%$ & $1,10 \%$ & $0,00 \%$ & $0,00 \%$ & $0,00 \%$ & $0,10 \%$ & $1,60 \%$ & $0,30 \%$ \\
\hline & $\begin{array}{l}\text { Tax incomes / other personal } \\
\text { incomes }\end{array}$ & $77,90 \%$ & $71 \%$ & $65 \%$ & $86,90 \%$ & $69,50 \%$ & $62,40 \%$ & $74,10 \%$ & $75,90 \%$ & $66,80 \%$ \\
\hline \multirow{5}{*}{ 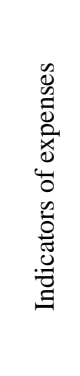 } & $\begin{array}{l}\text { Current operating balance / } \\
\text { current operating expenses }\end{array}$ & $-59,70 \%$ & $-52,40 \%$ & $-33,60 \%$ & $38,50 \%$ & $-59,70 \%$ & $-41,20 \%$ & $-76,30 \%$ & $-79,50 \%$ & $-78,30 \%$ \\
\hline & $\begin{array}{l}\text { Capital expenses / current } \\
\text { operating expenses }\end{array}$ & $21,40 \%$ & $19,70 \%$ & $27,50 \%$ & $51,00 \%$ & $15,80 \%$ & $25,40 \%$ & $3,70 \%$ & $4,10 \%$ & $15,40 \%$ \\
\hline & $\begin{array}{l}\text { Capital expenses / total } \\
\text { budget expenses }\end{array}$ & $27,20 \%$ & $24,60 \%$ & $37,90 \%$ & $105,20 \%$ & $24,20 \%$ & $34,20 \%$ & $3,90 \%$ & $4,30 \%$ & $18,20 \%$ \\
\hline & $\begin{array}{l}\text { LGU capital expenses per } \\
\text { capita/capital expenses of }\end{array}$ & & & & & & & & & \\
\hline & central budget per capita & $96,60 \%$ & $75,60 \%$ & $88,50 \%$ & $71,60 \%$ & $72,60 \%$ & $79,30 \%$ & $16,00 \%$ & $15,30 \%$ & $47,00 \%$ \\
\hline
\end{tabular}

Source: Own processing based on official data from the State Statistical Office of Republic of Macedonia and Finance Departments in all Local Government Units in Republic of Macedonia.

In the analyzed period, there is small increase of participation of tax incomes in total incomes, excluding rural municipalities, which indicates the fact that urban municipalities from Pelagonija planning region are in condition to generate increased level of tax incomes, which is a result of increasing the range of tax base, as well as the influence of increased fiscal effort due to transfer of competences from local to central level.

In the balance of current operating activities in terms of current operating expenses negative values are noted, which represents absence of credit potential of Local Government Units from this planning region for taking credit liabilities (borrowings).

Pelagonija planning region also notes small increase of capital expenses in terms of level of accomplishment of current operating expenses. This indicates high level of realization of financial resources intended for capital projects. This indicator indicates nearly same engagement of financial resources for current operating purposes, as for realization of capital projects. This is sufficient ascertainment for the commitment of this planning region in the realization of capital projects.

Analyzing the balance of capital expenses in terms of total budget expenses, it can be ascertained that the level of investing activity of municipalities from this region is relatively stable. This condition is a result of increased budget expenses in the analyzed period. 


\subsection{Polog Planning Region}

According to previously determined criteria for research realization, the municipalities Gostivar and Bogovinje were subject of research in Polog planning region.

Table 8. Fiscal indicators and indicators of expenses, Polog planning region, 2010, 2011 and 2012

\begin{tabular}{|c|c|c|c|c|c|c|c|}
\hline & \multirow{3}{*}{$\begin{array}{l}\text { REGION } \\
\text { CITY } \\
\text { REALIZATION PER YEAR } \\
\end{array}$} & \multicolumn{6}{|c|}{ POLOG REGION } \\
\hline & & \multicolumn{3}{|c|}{ GOSTIVAR } & \multicolumn{3}{|c|}{ BOGOVINJE } \\
\hline & & 2010 & 2011 & 2012 & 2010 & 2011 & 2012 \\
\hline \multirow{3}{*}{$\begin{array}{l}\text { Indicators } \\
\text { of incomes }\end{array}$} & Tax incomes / total incomes & $21,80 \%$ & $23,80 \%$ & $29,10 \%$ & $1,60 \%$ & $1,90 \%$ & $2,00 \%$ \\
\hline & Donations/ total incomes & $0 \%$ & $0,90 \%$ & $1,50 \%$ & $0,00 \%$ & $0,00 \%$ & $0,00 \%$ \\
\hline & Tax incomes / other personal incomes & $88,00 \%$ & $87,90 \%$ & $90,30 \%$ & $44,00 \%$ & $54,70 \%$ & $66,90 \%$ \\
\hline \multirow{4}{*}{$\begin{array}{l}\text { Indicators } \\
\text { of expenses }\end{array}$} & Current operating balance/current operating expenses & $66,50 \%$ & $-66,90 \%$ & $68,80 \%$ & $-80,90 \%$ & $-67,70 \%$ & $-62,40 \%$ \\
\hline & Capital expenses / current operating expenses & $43,20 \%$ & $13,60 \%$ & $38,90 \%$ & $9,80 \%$ & $7,20 \%$ & $15,30 \%$ \\
\hline & Capital expenses / total budget expenses & $76,50 \%$ & $15,80 \%$ & $67,60 \%$ & $15,70 \%$ & $11,20 \%$ & $18,20 \%$ \\
\hline & $\begin{array}{l}\text { LGU capital expenses per capita/capital expenses of } \\
\text { central budget per capita }\end{array}$ & $47,30 \%$ & $44,30 \%$ & $35,60 \%$ & $20,70 \%$ & $11,80 \%$ & $11,30 \%$ \\
\hline
\end{tabular}

Source: Own processing based on official data from the State Statistical Office of Republic of Macedonia and Finance Departments in all Local Government Units in Republic of Macedonia.

In the analyzed period, there is a small increase in participation of tax incomes in total incomes, which indicates the fact that urban municipalities from Polog planning region are in condition to generate increased level of tax incomes, which is a result of increasing the range of tax base, as well as the influence of increased fiscal effort due to transfer of competences from local to central level.

In the balance of current operating activities in terms of current operating expenses an increase is noted, which represents good credit potential of Local Government Units from this planning region for taking credit liabilities (borrowings).

Polog planning region notes flexibility of capital expenses in terms of level of accomplishment of current operating expenses. This indicates good level of realization of financial resources intended for capital projects. This indicator indicates same engagement of financial resources for current operating purposes, as for realization of capital projects. This is sufficient ascertainment for the commitment of this planning region in the realization of capital projects.

Analyzing the balance of capital expenses in terms of total budget expenses, it can be ascertained that the level of investing activity of municipalities from this region is relatively stable. This condition is a result of increased budget expenses in the analyzed period.

\subsection{Northeastern Planning Region}

According to previously determined criteria for research realization, the municipalities Kumanovo and Kratovo were subject of research in Northeastern planning region.

Table 9. Fiscal indicators and indicators of expenses, Northeast planning region, 2010, 2011 and 2012

\begin{tabular}{|c|c|c|c|c|c|c|c|}
\hline & \multirow{3}{*}{$\begin{array}{l}\text { REGION } \\
\text { CITY } \\
\text { REALIZATION PER YEAR }\end{array}$} & \multicolumn{6}{|c|}{ NORTHEAST REGION } \\
\hline & & \multicolumn{3}{|c|}{ KUMANOVO } & \multicolumn{3}{|c|}{ KRATOVO } \\
\hline & & 2010 & 2011 & 2012 & 2010 & 2011 & 2012 \\
\hline \multirow{3}{*}{$\begin{array}{l}\text { Indicators } \\
\text { of incomes }\end{array}$} & Tax incomes / total incomes & $22,10 \%$ & $23,90 \%$ & $44,50 \%$ & $13,50 \%$ & $8,80 \%$ & $5,30 \%$ \\
\hline & Donations/ total incomes & $0 \%$ & $0,10 \%$ & $0,00 \%$ & $0,00 \%$ & $0,30 \%$ & $2,30 \%$ \\
\hline & Tax incomes / other personal incomes & $78,20 \%$ & $80,20 \%$ & $74,80 \%$ & $72,60 \%$ & $63,20 \%$ & $48,10 \%$ \\
\hline \multirow{4}{*}{$\begin{array}{l}\text { Indicators } \\
\text { of expenses }\end{array}$} & Current operating balance / current operating expenses & $-66,30 \%$ & $-64,20 \%$ & $-7,30 \%$ & $-38,50 \%$ & $-85,60 \%$ & $-82,00 \%$ \\
\hline & Capital expenses / current operating expenses & $14,30 \%$ & $15,90 \%$ & $40,80 \%$ & $69,50 \%$ & $5,00 \%$ & $39,90 \%$ \\
\hline & Capital expenses / total budget expenses & $16,70 \%$ & $18,90 \%$ & $72,10 \%$ & $229,30 \%$ & $5,30 \%$ & $66,70 \%$ \\
\hline & $\begin{array}{l}\text { LGU capital expenses per capita /capital expenses of } \\
\text { central budget per capita }\end{array}$ & $63,20 \%$ & $60,20 \%$ & $88,00 \%$ & $193,70 \%$ & $17,60 \%$ & $162,30 \%$ \\
\hline
\end{tabular}

Source: Own processing based on official data from the State Statistical Office of Republic of Macedonia and Finance Departments in all Local Government Units in Republic of Macedonia. 
In the analyzed period, there is an increase in participation of tax incomes in total incomes, excluding rural municipalities, which indicates the fact that urban municipalities from Northeastern planning region are in condition to generate increased level of tax incomes, which is a result of increasing the range of tax base, as well as the influence of increased fiscal effort due to transfer of competences from local to central level.

In the balance of current operating activities in terms of current operating expenses, except at bigger municipality centers, an upward trend is noted, which represents good credit potential of Local Government Units from this planning region for taking credit liabilities (borrowings), while in rural municipalities this indicator notes downward trend, which indicates absence of credit potential. Northeastern planning region notes flexibility of capital expenses in terms of level of accomplishment of current operating expenses. This indicates good level of realization of financial resources intended for capital projects. This indicator indicates same engagement of financial resources for current operating purposes, as for realization of capital projects. This is sufficient ascertainment for the commitment of this planning region in the realization of capital projects.

Analyzing the balance of capital expenses in terms of total budget expenses, it can be ascertained that the level of investing activity of bigger municipalities is relatively stable, while at smaller municipalities this indicator indicates decrease of investing activity.

\subsection{Skopje Planning Region}

According to previously determined criteria for research realization, the municipalities Centar, KiselaVoda and Saraj were subject of research in Skopje planning region.

Table 10. Fiscal indicators and indicators of expenses, Skopje planning region, 2010, 2011 and 2012

\begin{tabular}{|c|c|c|c|c|c|c|c|c|c|c|}
\hline & \multirow{3}{*}{$\begin{array}{l}\text { REGION } \\
\text { CITY } \\
\text { REALIZATION PER YEAR } \\
\end{array}$} & \multicolumn{9}{|c|}{ SKOPJE REGION } \\
\hline & & \multicolumn{3}{|c|}{ CENTAR } & \multicolumn{3}{|c|}{ KISELA VODA } & \multicolumn{3}{|c|}{ SARAJ } \\
\hline & & 2010 & 2011 & 2012 & 2010 & 2011 & 2012 & 2010 & 2011 & 2012 \\
\hline \multirow{3}{*}{ 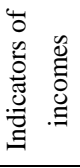 } & Tax incomes / total incomes & $25,70 \%$ & $27,20 \%$ & $18,40 \%$ & $28,60 \%$ & $35,50 \%$ & $49,90 \%$ & $9,60 \%$ & $49,60 \%$ & $54,90 \%$ \\
\hline & Donations/ total incomes & $0 \%$ & $0,00 \%$ & $0,00 \%$ & $0,00 \%$ & $0,20 \%$ & $0,00 \%$ & $2,80 \%$ & $1,20 \%$ & $0,00 \%$ \\
\hline & $\begin{array}{l}\text { Tax incomes / other personal } \\
\text { incomes }\end{array}$ & $74,60 \%$ & $87,70 \%$ & $61,20 \%$ & $72,80 \%$ & $76,60 \%$ & $74,80 \%$ & $90,10 \%$ & $88,20 \%$ & $87,60 \%$ \\
\hline \multirow{4}{*}{ 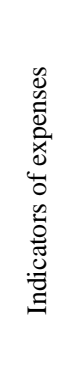 } & $\begin{array}{l}\text { Current operating balance / current } \\
\text { operating expenses }\end{array}$ & $180,30 \%$ & $164,10 \%$ & $12,20 \%$ & $-12,50 \%$ & $-34,90 \%$ & $-8,30 \%$ & $-87,80 \%$ & $19,90 \%$ & $38,90 \%$ \\
\hline & $\begin{array}{l}\text { Capital expenses / current operating } \\
\text { expenses }\end{array}$ & $52,80 \%$ & $86,60 \%$ & $77,90 \%$ & $29,50 \%$ & $24,40 \%$ & $41,60 \%$ & $11,50 \%$ & $51,10 \%$ & $53,90 \%$ \\
\hline & $\begin{array}{l}\text { Capital expenses / total budget } \\
\text { expenses }\end{array}$ & $431,60 \%$ & $652,80 \%$ & $355,10 \%$ & $42,00 \%$ & $32,40 \%$ & $72,10 \%$ & $13,10 \%$ & $108,10 \%$ & $123,50 \%$ \\
\hline & $\begin{array}{l}\text { LGU capital expenses per capita } \\
\text { /capital expenses of central budget } \\
\text { per capita }\end{array}$ & $651,60 \%$ & $850,20 \%$ & $998,40 \%$ & $70,70 \%$ & $76,70 \%$ & $159,10 \%$ & $31,70 \%$ & $28,40 \%$ & $46,40 \%$ \\
\hline
\end{tabular}

Source: Own processing based on official data from the State Statistical Office of Republic of Macedonia and Finance Departments in all Local Government Units in Republic of Macedonia.

In the analyzed period, there is flexibility in participation of tax incomes in total incomes, excluding rural municipalities, which indicates the fact that urban municipalities from Skopje planning region are in condition to generate increased level of tax incomes, which is a result of increasing the range of tax base, as well as the influence of increased fiscal effort due to transfer of competences from local to central level.

Skopje planning region also notes increase of capital expenses in terms of level of accomplishment of current operating expenses. This indicates high level of realization of financial resources intended for capital projects. This indicator indicates nearly same engagement of financial resources for current operating purposes, as for realization of capital projects. This is sufficient ascertainment for the commitment of this planning region in the realization of capital projects.

Analyzing the balance of capital expenses in terms of total budget expenses, an increase can be ascertained, which indicates increase of investing activity level of municipalities in this region. This condition is a result of increased budget expenses in the analyzed period. 


\section{Matrix of Indicators of Incomes and Expenses per Planning Regions}

According to previously made analysis of indicators of incomes and expenses at Local Government Units from the planning regions, it can be ascertained that at bigger municipalities there is increase of tax incomes in each planning regions, total incomes of municipalities, which is a result of increased range of tax base, thus charging the tax incomes.

According to the analysis, there is absence of credit potential in large part of the regions, considering the ascertained negative values of the indicator current operative balance on current operating activities, excluding Skopje planning region, wherein upward trends of this indicator are noted.

The municipalities from the planning regions, also note increase of capital expenses in terms of the level of accomplishment of current operating expenses. That indicates the fact that there is high level of realization of financial assets intended for capital projects. This is the case in larger municipalities from the planning regions.

From the analysis of the balance of capital expenses in terms of total budget expenses, it can be ascertained that the level of investing activity in bigger municipalities from the planning regions is relatively stable.

\section{Results}

The regional policy has special place in the development of national economies and economic integrations. The implementation of this policy contributes to economic and social cohesion of the regions, i.e. members in the economic integrations.

The regional development is of particular importance for Republic of Macedonia. This is because of inherited problems related to uneven regional development which has limiting effect on the rational use of available production resources and on the development not only of the regions, but the whole country. Considering the significance of the regional development policy, a particular attention should be paid to the creation and accomplishment of macroeconomic policy and development policy.

The research analysis show that without efficient regional policy, and in that context without support of economically underdeveloped areas, Republic of Macedonia will not be able to accomplish the transitional period successfully, and include in the globalization of the world economy. What is missed in this area should by compensated as fast as possible.

There are really big differences between the municipalities (regions) in Republic of Macedonia regarding their size, according to the number of citizens, regarding their area, rural, i.e. urban character, population density, economic characteristics, field configuration-mountainous or flat etc. According to this, the monotypic character of the municipalities should be left behind, and a polytypic character of them should be implemented, and according to that different kinds of municipalities would have different types of competences.

\section{References}

Acocella, N. (2005). Economic Policy in the Age of Globalisation. Cambridge University Press.

Association for Local Economic Development. (2005). Handbook for Creating LED Strategy. VNG International April.

Centre for Economic Analysis (CEA). (n. d.). The future of Local Government Finance-Case Stady from Romania, Bulgaria and Macedonia.

Douglass, C. N. (2006). Institutions, Institutional Change and Economic Performance. Cambridge University Press.

Edralin, J. S., Mani, D. S., \& Walter, B. (2001). Decentralization, Governance, and the New Planning for Local-Level Development. New Regional Development Paradigms, 3. Westport, CT: Greenwood Press.

Jankulovski, N. (2012). Financing local government units in the context of the regional development of the Republic of Macedonia. Doctorate, Institute of Economics, University St. Cyril and Methodius.

Kandeva, E. (2001). A Balkan Perspective-Introduction to Comparative Local Government in Central and Eastern Europe.

OECD. (1999). Revenue Statistics 1965/1998. Special Feature, OECD.

Ronald, S. (1999). Public Finance Review, 27(3). Sage Publications Inc.

State Secretariat for Euro integration. Retrieved from http://www.sep.gov.mk

State Statistical Office. Retrieved from http://www.stat.gov.mk 
Stöhr, W. B. (2001). A Key Concept for Regional Development Policy. In New Regions: Concepts, Issues, and Practices (Vol. 3). Westport, CT: Greenwood Press.

Thirlwall, A. P. (2003). Growth and Development-With Special Reference toDeveloping Economies. Palgrave.

Tsoukalis, L. (1997). The New European Economy: The Politics and Economy of Integration. Oxford University Press, New York.

Wilson, D. J. (1996). Capital Mobility and Environmental Standards: Is There a Theoretical Basis for a Race to the Bottom? Fair Trade and Harmonization, 1. Cambridge, Massachusetts: The MIT Press.

Wreston, F. J., Besley, S., \& Brigham, E. F. (1996). Essentials of managerial finance. The Dryden Press.

\section{Notes}

Note 1. NUTS 3-Republic of Macedonia is divided in eight planning regions: Vardar, Eastern, Southwestern, Southeasternern, Pelagonija, Polog, Northeastern and Skopje planning region

Note 2.Vardar region (Veles, Kavadarci and Caska), Eastern region (Stip, Probistip and Berovo), Southwestern region (Kicevo, Makedonski Brod and Oslomej), Southeastern region (Stumica, Valandovo and Dojran), Pelagonija region ( Bitola, Prilep and DemirHisar), Polog region (Gostivar and Bogovinje), Northeastern region (Kumanovo and Kratovo) and Skopje region (Centar, Kisela Voda and Saraj).

\section{Copyrights}

Copyright for this article is retained by the author(s), with first publication rights granted to the journal.

This is an open-access article distributed under the terms and conditions of the Creative Commons Attribution license (http://creativecommons.org/licenses/by/3.0/). 